$\square$

口-

Досліджено вплив часу та щільності бавовни-сирцю в бунті на зчіплюваність сору з бавовною. Визначено вплив зберігання бавовни-сирцю, а також волокна в ущільненому стані, що сприяе більщ швидкому проникненню бур'янів частинок вглиб матеріалу. У бавовни-сирцю, що зберігався в бунті 1 міс., при щіль-

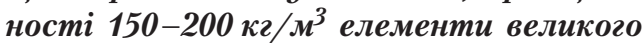
сору взаємодіяли з волокном із зусиллям 63-91 сH/2 листків, приквітка і стебла, а дрібного - 714-1000 сН/г. Після очищення, коли залишається лише дрібний сор, це зусилля зросло до 714-1053 сН/г. Ці дані відповідають бавовні-сирию І сорту. Для ІІІ сорту сила зчеплення дещо іниа -у великого сору - 76-96 cH/2, дрібного - 714-1267 сН/2, після очищення $-857-947 \mathrm{cH} / 2$.

Після тримісячного зберігання в бун-

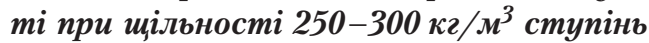
взаємодї̈ сміття з волокном для бавовни І сорту становила 109-137 $\mathrm{cH} / 2$, a III - 103-175 сH/г для великого сору. Розроблено технологічний режим, який визначає кратність очищення, а також запропонований метод визначення розпірних зусиль, що діють на живлячі валики $і$ є одним з найважливіших факторів енергоємності процесу. Проаналізована механіка процесу взаємодіi лопатей живлячого валика з шаром бавовни-сирцю, що транспортується. Результати досліджень дають можливість обрати потрібний режим в процесі очищення бавовни-сирцю від бур'янів домімок

Ключові слова: бавовна-сирець, бунт бавовни, валик, щільність бунту, зчіплюваність, сміттеві домішки, очищення, волокна

\title{
INFLUENCE OF STORAGE DURATION AND DENSITY OF RAW COTTON ON THE MECHANICS OF THE INTERACTION PROCESS BETWEEN FEEDING ROLLERS IN THE CLEANERS OF LARGE IMPURITIES
}

\author{
F. Veliev \\ Doctor of Technical Sciences, Professor* \\ R. S a ilov \\ $\mathrm{PhD}$, Associate Professor* \\ E-mail: ilmar@mail.ru \\ N. Kerimova \\ Doctor of Philosophy in Physics* \\ T. Safarova \\ $\mathrm{PhD*}$ \\ M. Is mailzade \\ $\mathrm{PhD}$, Associate Professor* \\ E. S u I t a nov \\ $\mathrm{PhD}$, Associate Professor* \\ *Department of technological machines \\ and equipment of the branch \\ Azerbaijan State University of Economics (UNEC) \\ Istiglyaliyat str., 6, Baku, Azerbaijan, AZ 1001
}

Long-term storage of raw cotton in bails in the compacted state contributes to the more rapid penetration of weed particles deep into raw cotton. This leads to the intensity of the cleaning process and increases the multiplicity of cleaning. The feed of cleaning machines should not cause any damage to fiber and cotton seeds under the action of its working bodies on raw cotton; it should not be accompanied by the forced introduction of weed particles into the fiber either.

Therefore, it is a relevant task to study influence of the raw cotton density in a bale on the adhesion with weedy impurities. Addressing this issue would make it possible to find the optimal variant for cleaning raw cotton from weedy impurities.

\section{Literature review and problem statement}

Paper [1] explored ways of enhancing the effectiveness of raw cotton cleaning from small weedy impurities by improving the grates. However, changing the profile of grates does not improve the effect of cotton cleaning from large impurities. Practical tests shown that under the action of impact between a pin and cotton at speed larger than $12 \mathrm{~m} / \mathrm{s}$ the seeds are damaged, which leads to an increase in the number of defects in fiber.

Study [2] addressed an influence of the lateral compaction of raw cotton in bale on cotton quality, as well as possibilities to improve performance of the feeder in the cotton ginning process. However, the authors failed to enhance performance efficiency over $2,000 \mathrm{~kg}$ per hour on fiber. In addition, an influence of density on adhesion between weedy impurities and raw cotton was not examined. 
Authors of [3] conducted research into improvement of the feeder mechanism in a cotton cleaner. They studied interaction between a pin and a raw cotton particle, which has a fibrous connection with cloth, formed by feeding rollers. The authors, however, did not achieve the desired cleaning effect for large impurities.

The result of research [4] is the prospects for the development of equipment and scientific base for raw cotton cleaning technology. However, influence of the feed mode on the effect of cleaning was not tackled.

Paper [5] examined the issues related to improving the technology of lateral compaction of raw cotton in bale in order to preserve its natural properties. The authors, however, failed to investigate influence of cotton density on quality indicators.

Study [6] examined the preparation of wet raw cotton for storage. However, the impact of cotton density on the adhesion with weedy impurities was not addressed.

In [7], authors investigated interaction between weedy impurities and cotton, but failed to study influence of density on adhesion between weedy impurities and cotton.

An analysis of scientific literature reveals that the issue of the influence of raw cotton density in bale on the adhesion with weedy impurities remains open.

\section{The aim and objectives of the study}

The aim of present work is to study influence of storage time and density of raw cotton in bale on the adhesion between weedy impurities and cotton, and to determine the magnitude of spreading forces that act on the feed rollers during raw cotton cleaning.

To accomplish the aim, the following tasks have been set: - to establish the mechanics of interaction between a feeding roller's blades of the cleaner and raw cotton;

- to choose a calculation method for the estimation of elastic characteristics of raw cotton and spreading forces of a feeding roller;

- to devise a procedure for evaluating the uniformity of feed of large impurities cleaners.

\section{Results of studying the influence of raw cotton density on the adhesion of weedy impurities and on the process of interaction between feeding rollers}

Raw cotton, as well as fibers in the compacted state, contribute to the faster penetration of impurities inside the material, which in practice leads to the increased multiplicity of cleaning. For the raw cotton stored in a bale for 1 month, at a density of $150-200 \mathrm{~kg} / \mathrm{m}^{3}$, the elements of large impurities interacted with the fiber with an effort of $63-91 \mathrm{sN} / \mathrm{g}$ for leaf, bract, and stem; those of small impurities - 714-1,000 sN/g.

Upon cleaning, when only small impurities remain, this effort grew to $714-1,053 \mathrm{sN} / \mathrm{g}$. These data correspond to cotton of grade I. For grade III, the adhesive force is slightly different: for large impurities - 76-96 sN/g, for small impurities $-714-1,267 \mathrm{sN} / \mathrm{g}$, after cleaning $-857-947 \mathrm{sN} / \mathrm{g}$.

After a three-month storage in bale, at a density of $250-300 \mathrm{~kg} / \mathrm{m}^{3}$, the degree of interaction between impurities and the fiber for cotton of grade I was $109-137 \mathrm{sN} / \mathrm{g}$, for grade III - 103-175 sN/g for large impurities. For small impurities, it was, respectively, 1,050-1,222 and
$1,118-1,400 \mathrm{sN} / \mathrm{g}$. After cleaning, these values for the latter varied in the range of $1,214-1,250$ and $1,118-1,400 \mathrm{sN} / \mathrm{g}$ [8].

There is an increased adhesiveness between impurities and the fiber, mostly due to the density of baling and, to a lesser extent, due to the storage period. This fact can be explained through the introduction of the concept of volumetric cotton impurity content. Cotton that contains weedy impurities is a complex composite, in which a certain volume is taken by seeds, fiber, weed particles, and air in the space between the fibers and other elements. Therefore, the state of such a composite, easily deformable, is not characterized fully by the impurity content:

$$
W_{m}=\frac{M_{c}}{M_{x}},
$$

where $M_{c}$ is the mass of impurities in the total mass of cotton $M_{x}$.

It is easy to show that at an insignificant impurity content the volumetric characteristic of the indicator can be represented in the form:

$$
W_{0}=\frac{v_{c}}{v_{x}}=\frac{\gamma_{x} W_{m}}{\gamma_{c}}
$$

where $v_{c}$ is the volume of impurities; $v_{x}$ is the volume of cotton; $\gamma_{c}$ and $\gamma_{x}$ is the density of impurities and cotton, respectively.

It is obvious from equation (2) that when $v_{c}$ and $\gamma_{c}$ are constant (which can be considered acceptable), the volumetric impurity content decreases with an increase in the volume of cotton, and vice versa. The latter means that the unit surface of a weed particle is contacted by the number of fibers in proportion to the degree of compaction of a material. This fact, as well as the storage duration of cotton that contains impurities, reveal the causes for the deterioration of technological properties of raw cotton as a cleaning material.

Therefore, the action of working bodies of technological machines on raw cotton should not damage the fiber and cotton seeds, which should not be accompanied by the forced penetration of weedy impurities into the fibers. The feeder must be assigned with a task to prepare raw cotton to the cleaning process. Through the disaggregation of structural particles and lumps of raw cotton and their deformation the feed unit of technological machines should in a sparing mode ensure an increase in the open surfaces of raw cotton, loosen bonds, and prepare the removal of weed particles from the fibrous mass related, in terms of their depth, to groups I-III.

4. 1. Determining the mechanics of an interaction process between the blades of a cleaner's feeding roller and raw cotton

We consider a problem on determining the magnitude of spreading forces acting on feeding rollers, which are one of the most important factors in the process energy intensity, strength conditions for blade rollers and, most significantly, the preservation of the material being processed.

In contrast to solutions proposed earlier [9] that consider the deformation of a layer by conditional round-shaped rollers, and raw cotton as a one-dimensionally deformable material, which is matched in elasticity theory by a material with the Poisson coefficient $\gamma=0$, in the proposed scheme, at the same condition for a flow continuity, it is proposed to describe a raw cotton deformation with blade rollers using the methods of contact problems from the theory of elasticity. 
It is assumed that the flow of raw cotton, deformed by blade rollers, is a semi-infinite perfectly elastic surface whose reactions on blades are predetermined by both local deformations of the layer and the common (if any) displacements of it. We consider both a symmetric case when reactions $P_{1}$, $P_{2}, P_{3}$ and $P_{1}^{\prime}, P_{2}^{\prime}, P_{3}^{\prime}$ are directed towards each other, with the layer surface displacements under the influence of these forces to be predetermined by local deformations only (Fig. 1), and a case of the asymmetric arrangement of blades when common layer displacements would also occur.

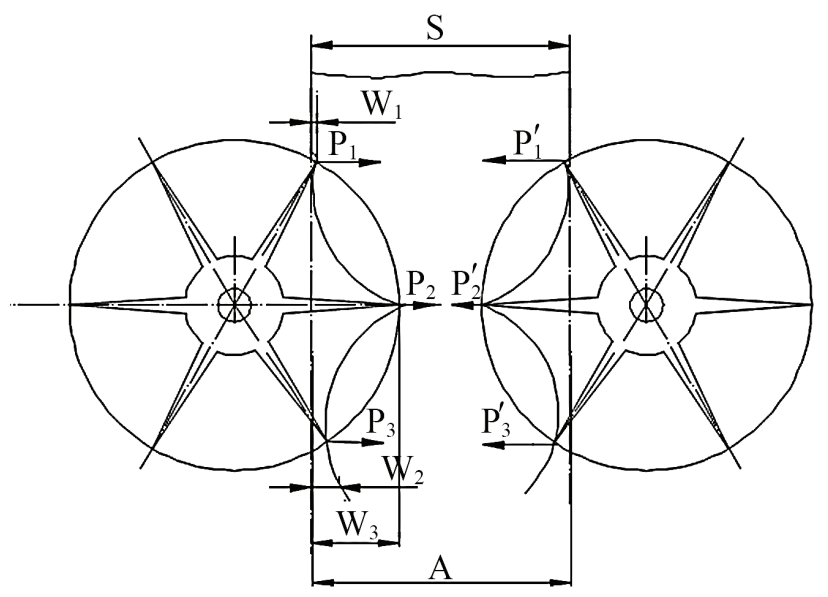

Fig. 1. Schematic of interaction between a feeding roller blades and a layer of raw cotton (symmetrical)

A Saint-Venant principle is applicable to this scheme [10, 11], according to which the application to a small part of the body surface of a system of forces leads to local deformations and stresses only, which decrease with the rate of geometric progression.

Given this, it is necessary to conduct a geometrical analysis into the deformation of a layer of raw cotton by roller blades. Assume that a cotton layer of thickness $S$ is being deformed by a feeding roller that contains $\mathrm{n}$ blades, arranged evenly along its circumference, with the central angle between its adjacent blades being equal to:

$$
\phi_{n}=\frac{2 \pi}{n}
$$

Diameters of rollers are denoted by $D$, and the inter-center distance between them - by $A$ (Fig. 2). The figures of the natural series of numbers denote the serial numbers of blades - in the direction opposite to the sequence of their contact with the product $-1,2,3, \ldots, n$.

The number of blades, which are simultaneously in the space of flow width $S$, and may have an impact on a layer of raw cotton, is a variable and can accept two values: $r_{\text {min }}$ :

$$
r_{\min }=\left[\frac{n \cdot \arccos \frac{A-s}{D}}{\pi}\right],
$$

where, according to [12], square brackets mark a nonelementary function, equal to the greatest integer, not exceeding the figure in brackets, and $r_{\text {max }}$ :

$$
r_{\max }=r_{\min }+1
$$

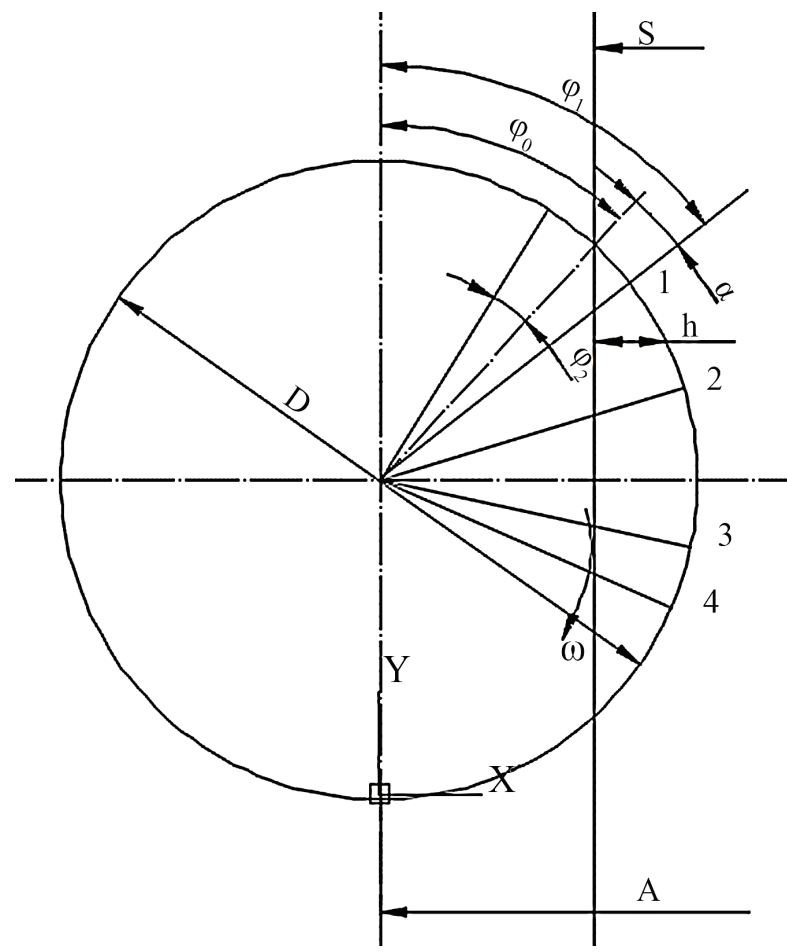

Fig. 2. Schematic of the penetration of roller blades into raw cotton

Let the roller rotates clockwise and the count of angles in this direction will start either from the vertical $O y$ $\phi_{i}$ axis for the $i$-th blade, or from the position of blade I at the time point of touch with a cotton layer, determined by magnitude $\phi_{0}$ :

$$
\varphi_{0}=\arcsin \frac{A-S}{D}, \quad \phi_{0}=\arcsin \frac{A-S}{D} .
$$

A full cycle of deformation of a raw cotton layer at the uniform arrangement of blades on the feed roller ends when blade I moves from position $\phi_{1}=\phi_{0} \varphi_{1}=\varphi_{0}$ to position:

$$
\phi_{1}=\phi_{0}+\frac{2 \pi}{n} \varphi_{1}=\varphi_{0}+\frac{2 \pi}{n},
$$

its place is taken by blade $n$.

For any intermediate position of blade I, the deformation of a layer in the direction perpendicular to its axis will be equal to:

$$
w_{1}=\frac{D}{2} \sin \phi_{1}-\frac{A-S}{2}=D \cos \frac{\phi_{1}+\phi_{0}}{2} \sin \frac{\phi_{1}-\phi_{9}}{2} .
$$

Denote $\phi_{1}-\phi_{0}=a$ and simplify (4):

$$
w_{1}=D \cos \left(\phi_{0}+\frac{\alpha}{2}\right) \sin \frac{\alpha}{2} \omega \omega_{1}=D \cos \left(\varphi_{0}+\frac{\alpha}{2}\right) \sin \frac{\alpha}{2} .
$$

For the $i$-th blade $\left(1 \leq i \leq r_{\max }\right)$, in a general case, we obtain:

$$
w_{i}=D \cos \left[\phi_{0}+\frac{\pi}{n}(i-1)+\frac{\alpha}{2}\right] \sin \left[\frac{\pi}{n}(i-1)+\frac{\alpha}{2}\right],
$$


in this case, we shall add a condition for non-negativity to this expression:

$$
w_{1} \geq 0
$$

Let us sum (8) for all blades that are in the region of possible contacts with raw cotton, assuming that a maximum of the geometrical sum will be matched with a maximum of the total deformation of an actual scheme and, therefore, a maximum of the total spreading force acting within the system. Upon introducing appropriate denotations, we shall obtain expression:

$$
\begin{aligned}
& \mathrm{w}_{\Sigma}=D \sum_{i=1}^{i=r} \cos \left[\phi_{0}+\frac{\pi}{n}(i-1)+\frac{\alpha}{2}\right] \sin \left[\frac{\pi}{n}(i-1)+\frac{\alpha}{2}\right] ; \\
& w_{\Sigma}=D \sum_{i=1}^{i=r} \cos \left[\varphi_{0}+\frac{\pi}{n}(i-1)+\frac{\alpha}{2}\right] \sin \left[\frac{\pi}{n}(i-1)+\frac{\alpha}{2}\right],
\end{aligned}
$$

which can be represented in the form convenient for differentiation.

An extremum (10) is derived from condition $\frac{\partial w_{\Sigma}}{\partial a}=0$ :

$$
\operatorname{tg} a_{d}=\frac{\sum_{i=1}^{i=r} \cos \left[\phi_{0}+\frac{2 \pi}{n}(i-1)\right]}{\sum_{i=1}^{i=r} \sin \left[\phi_{0}+\frac{2 \pi}{n}(i-1)\right]} \frac{\partial \mathrm{w}_{\Sigma}}{\partial \alpha}=0 .
$$

At values of $a_{0}$ that satisfy (11) and are located within the range determined by the accepted scheme of the process, the points of an extremum will be the maxima at $r_{\min }$ and $r_{\max }$ because:

$$
\frac{\partial^{2} w_{\Sigma}}{\partial a^{2}}<0
$$

Actually, with respect to (7), we obtain:

$$
\frac{\partial^{2} w_{\Sigma}}{\partial a^{2}}=-\left(w_{s}+\frac{D_{i}}{2} \sin \phi_{0}\right)<0 .
$$

The derived maxima of functions (10) are local, there are two of them over a deformation cycle, and they correspond to such a position of feed rollers when their blades are symmetrical relative to the line that connects rotation centers of rollers. This is evident from Table 1; it gives, together with other characteristics of the scheme, the values for angles $\alpha_{d}$ at $n=3,4,6$, and $8 ; A=210 \mathrm{~mm} ; D=140 \mathrm{~mm}$, and $S=180 \mathrm{~mm}$.

Table 1

Parameters of the feeder geometry
\begin{tabular}{|l|c|c|c|c|}
\hline \multirow{3}{*}{ Parameters } & \multicolumn{4}{c|}{ Number of blades, $n$} \\
\cline { 2 - 5 } & 3 & 4 & 6 & 8 \\
\hline$\phi_{0}$ & $12^{\circ} 22^{\prime}$ & $12^{\circ} 22^{\prime}$ & $12^{\circ} 22^{\prime}$ & $12^{\circ} 22^{\prime}$ \\
\hline$\phi_{n}$ & $120^{\circ}$ & $90^{\circ}$ & $60^{\circ}$ & $45^{\circ}$ \\
\hline \multirow{3}{*}{$r_{p}$, units } & 1,294 & 1,726 & 2,589 & 3,452 \\
\cline { 2 - 5 } & - & 1 & 2 & 3 \\
\cline { 2 - 5 } & - & 2 & 3 & 4 \\
\hline$a_{d}$ at $r=r_{\min }$ & $17^{\circ} 38^{\prime}$ & $32^{\circ} 38^{\prime}$ & $17^{\circ} 38^{\prime}$ & $12^{\circ} 8^{\prime}$ \\
\hline$a_{d}$ at $r=r_{\max }$ & $77^{\circ} 38^{\prime}$ & $77^{\circ} 38^{\prime}$ & $47^{\circ} 38^{\prime}$ & $32^{\circ} 38^{\prime}$ \\
\hline$w_{\text {max }}$ at $r_{\min }, \mathrm{mm}$ & 55 & 55 & 91,2 & 124 \\
\hline$w_{e}$ at $r_{\max }, \mathrm{mm}$ & 40 & 69 & 95 & 130,3 \\
\hline
\end{tabular}

4. 2. Substantiation of the method for calculating the elastic characteristics of raw cotton and spreading forces of the feeding roller

We shall define basic equations for a layer deformation. Assuming the smallness of the contact area compared to the total surface of bodies in contact, which corresponds to the problem considered here, the elasticity theory produces for a semi-space an expression to determine displacements w of body surface at distance $\rho$ from the point of application of the concentrated force $P$ (Boussinesq formula) [13]:

$$
W=\frac{1-v^{2}}{\pi E} \cdot k \frac{P}{p},
$$

where $E$ and $v$ are the elastic modulus and a Poisson's ratio of the deformed material, respectively; $k$ is a coefficient of generalized properties.

When load q is distributed at the contact site, the Boussinesq formula takes an integral form:

$$
W=k \int_{F} \frac{q}{p} \mathrm{~d} F,
$$

allowing us, for a preset load $q$, to determine displacements of points both at the contact site and beyond its limits, or, at the assigned displacement $w(\rho)$, to find an appropriate load distribution law (an inverse problem that requires solving an integral equation).

Solution (12) for a rectangular site indicates that at $q=$ const the displacement of the site's points is different. Thus, for a site with a length of $2 l$ and a width of $2 b$ the displacement of a center is equal to the magnitude (maximal):

$$
W_{0}=4 k q\left[b l_{n} \frac{\sqrt{b^{2}+l^{2}}+l}{b}+l \cdot l_{n} \frac{\sqrt{b^{2}+l^{2}}+b}{l}\right],
$$

and the vertices of right angles - the magnitude that is twice smaller.

In order not to reduce solving the problem to the analysis of complex integral equations, one applies a certain mean displacement $W_{c r}$ of the contact site assuming varying pressure $q(F)$, which is matched by the assigned mean magnitude $q$. This mean integral displacement:

$$
W_{c r}=\frac{\int_{F} W d F}{F} \text {. }
$$

whose solution for a rectangular site takes the form:

$$
W_{c r}=4 k q\left[\begin{array}{l}
b l_{n} \frac{\sqrt{b^{2}+l^{2}}+l}{b}+l l_{n} \frac{\sqrt{b^{2}+l^{2}}+b}{l}+ \\
+\frac{b^{3}+l^{3}-\left(b^{2}+l^{2}\right)^{\frac{3}{2}}}{3 b l}
\end{array}\right]
$$

and allows us to argue with reasonable accuracy about the magnitude of mean pressure $q$. Comparison of $q$ with the mean magnitude of pressure, obtained at $w=$ const, reveals that their values are not significantly different from each other.

To determine the numerical values of pressure forces of a blade on the flow of raw cotton, it is necessary to know magnitudes $E$ and $v$, coefficient of the generalized material properties $k$ [14]. 
For the SI system, power function coefficients accept the value of (for medium-fiber grades at humidity $7 \ldots 9 \%$ ) $m=11.4-11.54 ; n=0.3$ in the pressure interval $q=1-30 \mathrm{kN} / \mathrm{m}^{2}$.

For most actual materials, $v=0.25-0.3$; that can be accepted for raw cotton as well.

If we accept at $q_{0}=0$ the initial height of a prismatic volume of raw cotton of $h_{0}$ at the starting density $\gamma_{x 0}$, and the resulting height at $q$ of $h$, one can introduce a conditional magnitude for a relative deformation of cotton:

$$
\varepsilon=\left(h-h_{0}\right) / h_{0} .
$$

Table 2 gives estimated values of $q$ and $E$ for $\gamma_{x 0}=$ $=92 \mathrm{~kg} / \mathrm{m}^{3} ; m=11.54 ; n^{\prime}=0.3 v=0.25$ and $v=0$ (for the conditions of cotton deformation in a constrained volume).

Table 2

Table of estimated values for $q$ and $E$

\begin{tabular}{|c|c|c|c|c|}
\hline \multirow{2}{*}{$\varepsilon$} & \multicolumn{2}{|c|}{$q, \mathrm{~N} / \mathrm{m}^{2}$} & \multicolumn{2}{c|}{$E, \mathrm{~N} / \mathrm{m}^{2}$} \\
\cline { 2 - 5 } & $v=0$ & $v=0.25$ & $v=0$ & $v=0.25$ \\
\hline 0 & $1,012.2$ & $1,012.2$ & $3,374.1$ & $1,687.0$ \\
\hline 0.05 & $1,201.0$ & $1,105.5$ & $4,213.9$ & $2,059.2$ \\
\hline 0.1 & $1,438.1$ & $1,219.8$ & $5,326.4$ & $2,534.5$ \\
\hline 0.15 & $1,740.0$ & $1,361.3$ & $6,823.4$ & $3,151.6$ \\
\hline 0.20 & $2,129.6$ & $1,538.3$ & $8,873.5$ & $3,967.9$ \\
\hline 0.25 & $2,640.8$ & $1,762.8$ & $1,1736.9$ & $5,069.6$ \\
\hline 0.30 & $3,323.6$ & $2,052.2$ & $1,5826.8$ & $6,590.7$ \\
\hline 0.50 & $10,202.4$ & $4,652.5$ & $68,016.7$ & $24,124.3$ \\
\hline 0.70 & $56,001.8$ & $19,111.0$ & $622,242.7$ & $185,236.6$ \\
\hline 0.90 & $2,180,753.4$ & $563,680.2$ & $72,691,780$ & $18,022,423$ \\
\hline
\end{tabular}

\section{3. Procedure for estimating the uniformity of feed to} the cleaners of large impurities

It should be noted that known papers [5-7, 9, 15] place much emphasis on the issues of uniform controlled feed of processed product to cotton machines. This is particularly true for the cleaners of large impurities.

Given that for many processes it would suffice to ensure the uniformity of feed across the width of a machine over prolonged time, for the case when the flow is distributed at the working surface employed to carry out a technological process the specified feed is unacceptable. Here one needs to scatter the fed product with respect to feed rate or the speed of transportation in space, that is, to estimate the feeding system in space and time.

Based on these premises, we estimated under laboratory conditions the uniformity of a cleaner feed at a specialized bench at which the supplied product was scattered on an endless belt at a rate close to the speed of cotton motion when it reaches the surface of a pin drum $-22 \mathrm{~m} / \mathrm{min}$.

We accepted, as the first criterion for feed uniformity, a ratio of area $S_{x}$ taken by raw cotton at the belt to the total area of considered belt section $S_{0}$.

$$
S_{y g}=\frac{S_{x}}{S_{0}} \leq 1 .
$$

A given magnitude was the key one in the experiment to determine the extent of the non-uniformity of material feed by feeding devices and in the limit it should tend to unity.
After passing the unit of pre-cleaning and upon reaching a serrated drum, and after the fixing device, cotton will accept a different value of $S_{y g}$; however, by copying the original form of the flow the new value for this criterion will be a function of the initial one.

Another criterion to complement the first one will be the filling of the regions of area $S_{x}$ with cotton mass $M_{x}$ :

$$
K_{M}=\frac{M_{x}}{S_{x}},
$$

that is the mean density of a layer. At the same time, the total density of a cotton layer at the considered belt section will be equal to:

$$
K_{0}=\frac{M_{x}}{S_{0}}=K_{M} \cdot S_{y g} .
$$

Criteria $K_{M}, K_{0}$ and $S_{y g}$ can be applied both to a general and specific estimation of the uniformity of feed at the predefined point or the belt area or under the assigned conditions for a non-uniform process. Such particular estimations yield statistics - the arithmetic mean and a variance of the examined magnitude.

Thus, for $K_{M}$ and $K_{0}$ at known $n$ particular values for the criteria, the variance will equal to:

$$
S_{(k)}=\sqrt{\frac{\sum_{i=1}^{i=n}\left(K_{i}-K_{c r}\right)^{2}}{n-1}} .
$$

The value of $S_{(k)}$ allows us to argue with a reasonable accuracy about the degree of stability of the uniform feed of the with of raw cotton, and the magnitude of a variance coefficient:

$$
C=\frac{S_{(k)}}{k} \cdot 100 \% \text {. }
$$

In the experiments, we conducted a comparative estimation of the uniformity of feed to the cleaner from the feeding rollers of two designs - blade rollers, produced industrially, and pin rollers that include drums with a diameter of $85 \mathrm{~mm}$ and pins with a height of $29 \mathrm{~mm}$ with a pitch of the drum shell of $50 \mathrm{~mm}$.

At feeding speed $n=8 \mathrm{rpm}$ and a material density in the mine of $\gamma=72 \mathrm{~kg} / \mathrm{m}^{3}$, we obtained the following values for the specific area taken by raw cotton: for a blade roller $S_{y g}=0.54$ for a pin roller $-S_{y g}=0.808$.

It is obvious that there is no need to calculate $K_{M}$ and $K_{0}$ at the same performance efficiency of feeding rollers, which corresponds to the conditions of the experiment, $K_{m}^{l} / K_{m}^{k}=1.496 ; K_{0}^{l}=K_{0}^{k}$. This testifies to a more uniform feed of the machine using pin rollers.

\section{Discussion of results of studying the influence of raw cotton density on the adhesion of impurities, and estimating the uniformity of feed to the cleaners of large impurities}

Our research identified interactions between small and large impurities and fiber. The higher density of raw cotton in a bale, the stronger the force of adhesion between raw cotton 
and impurities. Enhanced adhesion between impurities and raw cotton can be explained by the cotton volumetric impurity content. Therefore, storing raw cotton in bales requires that its density should not exceed 200-250 kg.

Our study is continuation of earlier studies [14,15]. Results of the undertaken research could be applied in the cotton cleaning industry.

The results obtained are important because designing a feeding system includes elements for the preparation of raw cotton to cleaning processes by a targeted change in the technological properties of cotton. It should also be noted that the proposed system takes into consideration a solution to the task on the deformation of structural particles of cotton, obtained both numerically and through the experimentally defined magnitudes of spreading, inclination angles of pins at loosening rollers in the processes of implementation, capture, deformation, and auto-discharge. Thus, we consider to be a fully substantiated conclusion on the qualitative development of a system of uniform feed of cotton machines, in particular, the development of criteria for the uniformity of a product feed based on mass and geometrical parameters.

The benefits of present research when compared with analogues demonstrate that theoretical calculations account for the most important technological characteristics of raw cotton. Specifically, the magnitude of effective open surface of cotton structural particles calculated per cotton unit mass. It is clear that it is linked to a structure coefficient $-E$ and $v$, coefficient of the generalized properties of a material $k$, and a loosening degree of mass; it correlates to the capability of cotton to isolate weedy impurities.

\section{Conclusions}

1. Our study revealed that in the raw cotton stored in bale the elements of impurities interact with the fiber at an effort of $63-91 \mathrm{sN} / \mathrm{g}$ for large impurities, and $714-1,000 \mathrm{sN} / \mathrm{g}$ for small impurities. Upon the expire of the duration of effort, the interactions grow. Enhanced adhesion between impurities and fiber occurs due to the density of cotton in bale.

2 . We have developed a procedure for estimating the cotton impurity content using spatial characteristics that determine the degree of interaction between the fiber and weedy impurities in different states of raw cotton. A technique was devised to identify the specified technological characteristics; its distinctive feature is the fixation of the volume of raw cotton in the predefined state and subsequent obtaining and analysis of control samples.

3. We have established a mechanics of the process of interaction between a feeding roller blades and the transported layer of raw cotton. We examined systems of uniform feed of cotton machines taking into account the development of criteria for the uniformity of a product feed based on mass and geometrical parameters. We have solved a problem on the deformation of a layer by blade rollers; and determined analytically the deformations of a raw cotton layer for any intermediate position of the blade, and, therefore, a maximum of the total spreading force in the system.

4. A comprehensive analysis is proposed for the system of feeding with a symmetric arrangement of blades of feeding rollers; we estimated the power consumed by the feeding rollers; in addition, we established patterns in the uniformity of feed to the feeding blade rollers for the designs produced industrially.

\section{References}

1. Kadyrov B. G., Tursunov H. K., Aripdkanov M. Issledovanie dvizheniya hlopka-syrca v ochistitelyah ot krupnogo sora // Hlopkovaya promyshlennost'. 1982. Issue 1. P. 15-16.

2. Tyutin P. N., Lugachev L. E. O vydelenii sornyh primesey cherez yacheyki setchatyh poverhnostey // Mekhanicheskaya tekhnologiya voloknistyh materialov. 1977. Issue 19. P. 51-58.

3. Baydyuk P. V. Primenenie valkovyh ustroystv pri pressovanii voloknistyh materialov // CINTI. 1964. Issue 4. P. 2-8.

4. Sultanov A. Issledovanie po izyskaniyu optimal'nyh sposobov ochistki hlopka-syrca ot melkogo sora. Tashkent: TITLP, 1980. 169 p.

5. Miroshnichenko G. I., Burnashev R. Z., Lugachev A. E. Sposob pitaniya mashiny po obrabotke hlopka-syrca. Avtorskoe svidetel'stvo No. 524870. declareted: 15.08.1976, Bul. No. 30.

6. Hafizov I. K., Rasulov A. Issledovanie razryhlitel'nogo effekta razdelitelya dolek tonkovoloknistogo hlopka-syrca na letuchki // Hlopkovaya promyshlennost'. 1979. Issue 3. P. 9.

7. Miroshnichenko G. I., Burnashev R. Z. Vybor parametrov ustroystv dlya izmeneniya napravleniya dvizheniya semyan // Hlopkovaya promyshlennost'. 1973. Issue 3. P. 20.

8. Prochnost', ustoychivost', kolebaniya. Spravochnik v trekh tomah. Vol. 1 / M. I. Birgera, Ya. G. Panovko (Eds.). Moscow: Mashinostroenie, 1968. $464 \mathrm{p}$.

9. Bronshteyn I. P., Semendyaev K. A. Spravochnik po matematike. Moscow: «Nauka», 1981. 720 p.

10. Prochnost', ustoychivost', kolebaniya. Spravochnik v trekh tomah. Vol. 3 / M. I. Birgera, Ya. G. Panovko (Eds.). Moscow: Mashinostroenie, 1968. $568 \mathrm{p}$.

11. Sailov R. A., Veliev F. A., Kerimov Q. K. Research into the process of mechanical formation of the upper part of a raw cotton bundle // Eastern-European Journal of Enterprise Technologies. 2017. Vol. 4, Issue 1 (88). P. 56-63. doi: 10.15587/1729-4061.2017.108948

12. Sailov R. A., Veliev F. A., Kerimov Q. K. Determination of the heat distribution in the raw cotton packed in the coil // EUREKA: Physics and Engineering. 2017. Issue 3. P. 3-11. doi: 10.21303/2461-4262.2017.00359

13. Pervichnaya obrabotka hlopka / Dzhabarov G. D., Baltabaev S. D. et. al. Moscow: Legkaya industriya, 1978. 430 p. 